\title{
Cyclic Adenosine Monophosphate-dependent Kinase in Cystic Fibrosis Tracheal Epithelium
}

\author{
Roger Barthelson and Jonathan Widdicombe \\ Cardiovascular Research Institute, University of California San Francisco, San Francisco, California 94143
}

\begin{abstract}
$\mathrm{Cl}^{-}$impermeability in cystic fibrosis (CF) tracheal epithelium derives from a deficiency in the $\beta$-adrenergic regulation of apical membrane $\mathrm{Cl}^{-}$channels. To test the possibility that cAMP-dependent kinase is the cause of this deficiency, we assayed this kinase in soluble fractions from cultured airway epithelial cells, including CF human tracheal epithelial cells. Varying levels of cAMP were used in these assays to derive both a $V_{\max }$ and apparent dissociation constant $\left(K_{d}\right)$ for the enzymes in soluble extracts. The cAMP-dependent protein kinase from CF human tracheal epithelial cells has essentially the same $V_{\max }$ and apparent $K_{\mathrm{d}}$ as non-CF human, bovine, and dog tracheal epithelial cells. Thus, the total activity of the cAMP-dependent kinases and their overall responsiveness to cAMP are unchanged in $\mathrm{CF}$.
\end{abstract}

\section{Introduction}

Cystic fibrosis $(\mathrm{CF})^{1}$ is an inherited disorder characterized by deficient $\mathrm{Cl}^{-}$permeability in epithelia, including those of the sweat gland duct (1) and the airways $(2,3) \cdot \mathrm{Cl}^{-}$impermeability in $\mathrm{CF}$ secretory epithelia probably reflects a deficiency in the $\beta$-adrenergic regulation of apical membrane $\mathrm{Cl}^{-}$channels. In the coil of the normal human sweat gland, fluid secretion is stimulated by methacholine and isoproterenol, but in individuals with $\mathrm{CF}$, only methacholine stimulates (4). In airway epithelium, $\beta$-adrenergic agents are potent stimulators of $\mathrm{Cl}^{-}$secretion, and cAMP serves as second messenger in this response (5). Recent Ussing chamber studies show that $\mathrm{Cl}^{-}$secretion across human tracheal epithelial cells can be stimulated by isoproterenol, and by $\mathrm{A} 23187$ in the presence of $\mathrm{Ca}^{2+}$. With CF human tracheal epithelial cells, A23187 can elicit a response, but not isoproterenol (6). Similarly, patch clamp studies of human tracheal epithelial cells demonstrate the presence of functional apical membrane $\mathrm{Cl}^{-}$channels in CF cells, but these channels fail to open in response to $\beta$-adrenergic stimulation $(7,8)$.

Received for publication 22 June 1987 and in revised form 26 August 1987.

1. Abbreviations used in this paper: $\mathrm{CF}$, cystic fibrosis; $K_{\mathrm{ap}}$, apparent affinity constant.

J. Clin. Invest.

(c) The American Society for Clinical Investigation, Inc. $0021-9738 / 87 / 12 / 1799 / 04 \$ 2.00$

Volume 80, December 1987, 1799-1802
The lack of response to $\beta$-adrenergic agonists by CF cells does not involve a problem with the activation of adenylate cyclase; intracellular levels of cAMP rise by similar amounts in $\mathrm{CF}$ and non-CF tracheal epithelial cells treated with isoproterenol $(6,8)$. Elevated cAMP levels are probably linked to increased $\mathrm{Cl}^{-}$secretion by the cAMP-dependent protein kinase (9). Regulation of ion transport by activation of the cAMP-dependent kinase has been described in a number of systems $(10,11)$.

The following experiments test for a possible deficiency in the cAMP-dependent kinase in cultured CF tracheal epithelial cells. Levels of the kinase activity were compared for cell extracts from cattle, dog, and humans, both with and without CF. Cultures of bovine and canine cells behave identically to cultured human cells in Ussing chamber studies of ion transport (12). Dog tracheal cells respond in a manner qualitatively identical to the original epithelium (13).

\section{Methods}

$\gamma-\left[{ }^{32} \mathrm{P}\right]-\mathrm{ATP}$ was obtained from NEN DuPont Co., Wilmington, DE. All other biochemicals were from Sigma Chemical Co., St. Louis, MO.

Tracheal epithelial cells were grown on $60-\mathrm{mm}$ dishes coated with human placental collagen as described previously $(12,13)$. The cells were washed in PBS, scraped from the dishes with a rubber policeman, and centrifuged at $1,000 \mathrm{~g}$. The pellet was resuspended in homogenization buffer and sonicated on ice for $1 \mathrm{~min}$ with a sonic dismembrator (Quigley Co., Inc., Rochester, NY), using the needle tip. Homogenization buffer consisted of $20 \mathrm{mM}$ Tris/ $\mathrm{HCl}, \mathrm{pH} 7.5,0.5 \mathrm{mM}$ EGTA, 1.0 $\mathrm{mM}$ dithiothreitol, and three protease inhibitors in $0.1 \% \mathrm{NP}-40$, diluted into the buffer to give $2 \mathrm{mM}$ benzamidine, $1 \mu \mathrm{g} / \mathrm{ml}$ leupeptin, 0.1 $\mu \mathrm{g} / \mathrm{ml}$ pepstatin, and $0.01 \% \mathrm{NP}-40$. Cell sonicates were centrifuged at $1,000 \mathrm{~g}$ to remove unbroken cells and then separated into supernatant and membrane fractions by centrifugation at $47,000 \mathrm{~g}$ for $1.5 \mathrm{~h}$. Cell extracts were stored at $-100^{\circ} \mathrm{C}$.

Transfer of $\left[{ }^{32} \mathrm{P}\right]-\mathrm{PO}_{4}$ from $\gamma$ - $\left[{ }^{32} \mathrm{P}\right]-\mathrm{ATP}$ to the acceptor histone was assayed essentially as described by Burnham and Williams (14). The following mixture was incubated at $30^{\circ} \mathrm{C}: 20 \mathrm{mM}$ Pipes buffer, $\mathrm{pH} 7.0$, $5 \mathrm{mM} \mathrm{MgCl} 2,0.1 \mathrm{mM}$ EGTA, $30 \mu \mathrm{g} / \mathrm{ml}$ supernatant protein or 60 $\mu \mathrm{g} / \mathrm{ml} \mathrm{membrane} \mathrm{protein,} 0.5 \mathrm{mg} / \mathrm{ml}$ histone, and $25 \mu \mathrm{M} \gamma-\left[{ }^{32} \mathrm{P}\right]-\mathrm{ATP}$, $\sim 15,000 \mathrm{cpm} / \mu \mathrm{l}$. Timed $100-\mu \mathrm{l}$ samples were removed and added to 4 $\mathrm{ml}$ of $5 \%$ TCA, $1.5 \%$ sodium pyrophosphate, and $1.0 \%$ sodium phosphate (monobasic). These precipitated samples were filtered on HATF $25 \mathrm{~mm} / 0.45 \mu \mathrm{M}$ filters (Millipore/Continental Water Systems, Bedford, MA). The filters were washed eight times with $2 \mathrm{ml}$ of the acid mixture, and their radioactivity was measured with an aqueous scintillation mixture in a scintillation counter. Control experiments showed that eight rinses were sufficient to reduce radioactivity from the reaction mixture to a level not more than twice the background level of $30 \mathrm{cpm}$. In the absence of cAMP, $\sim 1,000 \mathrm{cpm}$ were transferred to the sample per minute. For the experiments with varying concentrations of CAMP, duplicate samples were taken at $6 \mathrm{~min}$ to 
determine the rate of phosphate incorporation into histone. Isobutylmethylxanthine $(1 \mathrm{mM})$ was added to the reaction mixture of some preliminary experiments, but it had no significant effect on phosphorylation and was omitted from all histone kinase assays.

For phosphorylation of endogenous proteins, the same incubation conditions as just described were used, except protein concentration was $0.2 \mathrm{mg} / \mathrm{ml}$, EGTA was $0.3 \mathrm{mM}$, isobutylmethylxanthine was 1 $\mathrm{mM}, \gamma-\left[{ }^{32} \mathrm{P}\right]-\mathrm{ATP}$ was $2.5 \mu \mathrm{M}, 70 \mu \mathrm{Ci} / \mathrm{ml}$. Samples $(100 \mu \mathrm{l})$ were incubated for $2 \mathrm{~min}$ at $30^{\circ} \mathrm{C}$. The reaction was quenched by the addition of $25 \mu \mathrm{l}$ of a solution of $100 \mathrm{mM}$ EDTA, $100 \mathrm{mM} \mathrm{NaF}$, and $5 \mathrm{mM}$ ATP. Samples were chilled on ice, and $100 \mu \mathrm{l}$ each was passed through a G-50 Sephadex column (15) to remove radioactive ATP. A sample $(64 \mu \mathrm{l})$ of the void fraction was prepared and run on SDS-polyacrylamide gel electrophoresis using 10\% acrylamide as described (16).

\section{Results and Discussion}

Activity of the cAMP-dependent kinase was measured as the cAMP-stimulated incorporation of $\left[{ }^{32} \mathrm{P}\right] \mathrm{PO}_{4}$ from $\gamma-\left[{ }^{32} \mathrm{P}\right]-\mathrm{ATP}$ into the exogenous phosphate acceptor histone. Fig. 1 shows the results of the cAMP-dependent kinase assay for the highspeed supernatant fraction from dog tracheal epithelial cells. Incorporation of $\left[{ }^{32} \mathrm{P}^{3} \mathrm{PO}_{4}\right.$ was dependent on the presence of both histone and cystosolic protein and was linear with time for at least $8 \mathrm{~min}$ even in the presence of supramaximal concentrations of cAMP (Fig. 1).

Most of the cAMP-dependent kinase activity was found in the soluble fraction. For example, the pellet portion for human cells had a maximum of $15 \mathrm{pmol} \cdot \mathrm{mg}^{-1} \cdot \mathrm{min}^{-1}$ activity, which was only a $10 \%$ increase over baseline phosphate incorporation for these experiments, and only $4 \%$ of the mean activity in the supernatants. This relatively low association of the kinase with the membrane fraction does not necessarily reflect the physiological distribution of the enzyme, because the association of the kinase with membranes can be affected by ionic strength (17) and possibly by metal chelators.

Fig. 2 shows examples cAMP-dependent phosphorylation of endogenous proteins separated by SDS-PAGE. As expected from the data on histone phosphorylation, no cAMP-dependent kinase activity towards endogenous acceptors was present in the membrane fraction (lane $C$ ), whereas cAMP caused a very large increase in phosphorylation of supernatant proteins

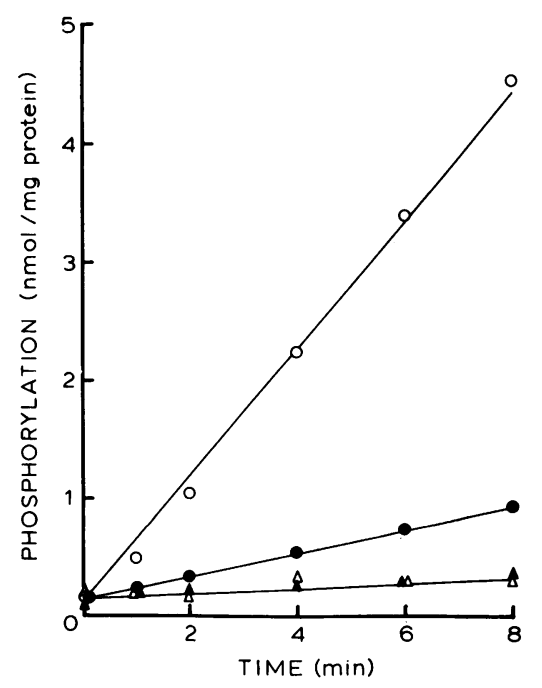

Figure 1. Phosphorylation of histone by cell extracts from dog tracheal epithelial cells in culture: $(\boldsymbol{\Lambda})$ with histone alone; $(\Delta)$ with supernatant protein alone; (•) with both supernatant proteins and histone, but no cAMP; (O) with supernatant proteins, histone, and CAMP (2 $\left.\times 10^{-6} \mathrm{M}\right)$. Values are normalized to the amount of supernatant protein present. When histone alone was added, phosphate levels were normalized to the protein content of the other samples.

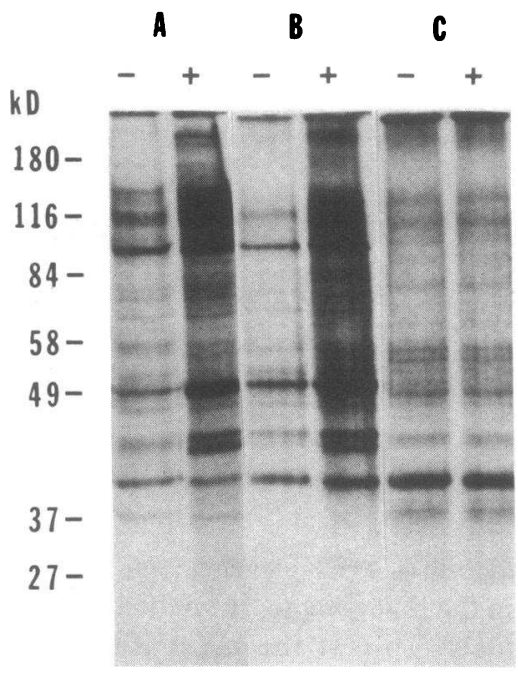

Figure 2. Autoradiogram of phosphorylated proteins from human tracheal epithelial cells. Cell extracts were incubated in the presence of $\gamma-\left[{ }^{32} \mathrm{P}\right]-\mathrm{ATP}$, in absence $(-)$ and presence $(+)$ of cAMP $\left(2 \times 10^{-6} \mathrm{M}\right)$, and then were subjected to PAGE (10\% acrylamide) and autoradiography. Lanes: $(A)$ supernatant proteins from non-CF cells; $(B)$ supernatant proteins from CF cells; $(C)$ pellet proteins from non-CF cells.

(lanes $A$ and $B$ ). There was essentially no difference in kinase activities in the soluble fractions of non-CF (lane $A$ ), and $\mathrm{CF}$ (lane $B$ ) cell extracts.

Supernatant proteins and histone were incubated with varying concentrations of cAMP to determine the sensitivity of the kinase activity to cAMP. The cAMP-dependent kinases in many tissues consist of at least two different holoenzymes, each constructed of interchangeable catalytic subunits and differing regulatory subunits $(18,19)$. Because it is the regulatory subunit that binds cAMP, these experiments yield an apparent affinity constant $\left(K_{\mathrm{ap}}\right)$ for the binding of cAMP to the collective holoenzymes in the supernatant fraction.

Soluble fractions from all the tracheal epithelial cells show a typical saturation binding curve for cAMP activation of kinase activity (Fig. 3). Eadie-Hofstee analysis of these data gives a $K_{\text {ap }}$ ranging from $1.3 \times 10^{8}$ to $2.3 \times 10^{8}$ for tracheal cells of the three species tested (Table I). These values are near to those

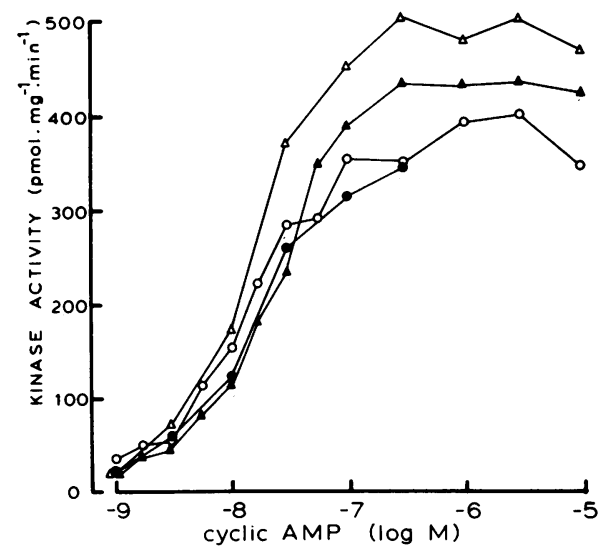

Figure 3. cAMP-dependent kinase activity at different concentrations of cAMP in soluble fractions from tracheal epithelial cells in culture. The difference between the rates of phosphate incorporation for the experimental (+cAMP) and control incubations was calculated for $(\Delta)$ bovine, $(\Delta)$ canine, and both $(0)$ non-CF and $(\bullet) C F$ human tracheal epithelial cells. Each curve represents the mean data for four experiments from two batches of cells for bovine cells, three from two for dog, seven from three for non-CF, and three from two for CF cells. 
described for the pancreas (14) and for skeletal muscle (20). In muscle, the exact $K_{\mathrm{d}}$ for cAMP depends on the concentration of ATP $\left(+\mathrm{Mg}^{2+}\right)$ and of the phosphate acceptor. The $K_{\mathrm{ap}}$ of $\sim 1.5 \times 10^{-8} \mathrm{M}$ observed here for $25 \mu \mathrm{M}$ ATP falls above a $K_{\mathrm{d}}$ of $6 \times 10^{-9} \mathrm{M}$ given by Beavo (20) for cAMP binding in the absence of ATP and is considerably lower than the $K_{\mathrm{d}}$ of 6 $\times 10^{-7} \mathrm{M}$ for kinase activity in muscle extracts in the presence of $125 \mu \mathrm{M}$ ATP. Table I shows that the $K_{\mathrm{ap}}$ for tracheal epithelial cells from all three species are very similar.

Similarly, Table I shows that the $V_{\max }$ for cAMP-dependent kinase activity (normalized to supernatant protein) is also very similar for tracheal epithelial cells from the three species tested. The maximal activity seen in these tracheal epithelial cells $\left(350-500 \mathrm{pmol} \cdot \mathrm{mg}^{-1} \cdot \mathrm{min}^{-1}\right)$ is higher than that reported for mouse pancreatic acinar cells, $(100 \mathrm{pmol}$. $\left.\mathrm{mg}^{-1} \cdot \mathrm{min}^{-1}\right)(14)$, and lower than that found for rabbit skeletal muscle $\left(690 \mathrm{pmol} \cdot \mathrm{mg}^{-1} \cdot \mathrm{min}^{-1}\right)(21)$.

Epithelial cells cultured from tracheas of patients with CF show normal protein kinase activity in response to cAMP. Fig. 3 shows that the dose-response curve for cAMP-dependent kinase activity in the $\mathrm{CF}$ cells follows very closely the activity in non-CF human cells. The mean $K_{\text {ap }}$ and $V_{\max }$ (normalized to supernatant protein) from these experiments are also not significantly different from those for non-CF human cells (Table I).

These data indicate that the predominant cAMP-dependent kinase activity is essentially the same in non-CF and CF tissue. However, these experiments do not distinguish between the different regulatory subunits or catalytic subunits (22) which may be present in trachea, nor do they consider the possible segregation of a subpopulation of holoenzyme into a subcellular compartment that may be critical to the regulation of $\mathrm{Cl}^{-}$secretion. For example, in cardiac myocytes (23), the protein kinase that regulates glycogen hydrolysis is in the gly-

Table I. Summary of $V_{\max }$ and $K_{a p}$ Values for all Epithelial Cells Tested

\begin{tabular}{llll}
\hline Source of epithelial cells & $V_{\max }$ & $K_{\mathrm{ap}}$ & $n$ \\
\hline & $p m o l \cdot \mathrm{mg}^{-1} \cdot \mathrm{min}^{-1}$ & $\times 10^{8} \mathrm{M}$ & \\
Bovine trachea, combined & $516 \pm 18$ & $1.6 \pm 0.2$ & 4 \\
Canine trachea, combined & $449 \pm 10$ & $2.3 \pm 0.2$ & 3 \\
Human (non-CF) & & & \\
Trachea 1 & $474 \pm 35$ & $1.3 \pm 0.3$ & 3 \\
Trachea 2 & $355 \pm 25$ & $1.1 \pm 0.3$ & 3 \\
Trachea 3 & $193 \pm 13$ & $1.3 \pm 0.3$ & 1 \\
Combined & $378 \pm 11$ & $1.3 \pm 0.1$ & 7 \\
Human (CF) & & & \\
Trachea 1 & $471 \pm 19$ & $1.3 \pm 0.3$ & 1 \\
Trachea 2 & $244 \pm 9$ & $1.6 \pm 0.2$ & 2 \\
Combined & $359 \pm 19$ & $1.4 \pm 0.3$ & 3 \\
& & & \\
\hline
\end{tabular}

Values are means $\pm \mathrm{SE}$ from computer-fitted least squares nonlinear regression analysis. $n$, number of experiments. Experiments were performed on two separate batches of both bovine and canine cells. For individual tracheas, $V_{\max }$ and $K_{\mathrm{ap}}$ were obtained from the curves fitted to the means of the kinase activities from all the individual experiments on that tracheal preparation. "Combined" values were derived from the fit to the mean kinase activities of all the experiments, as illustrated in Fig. 3. No attempt was made to weight the results for differences in the numbers of experiments performed per trachea. cogen granules. In tracheal epithelium, isoproterenol acts from the serosal side of the tissue, thus activation of apical membrane $\mathrm{Cl}^{-}$channels must involve cytosolic messengers, and these may include the protein kinase itself. The specific holoenzyme that regulates $\mathrm{Cl}^{-}$secretion may, nonetheless, be associated with the plasma membrane or otherwise represent a small fraction of the total kinase activity.

Whatever the composition of the holoenzymes in the trachea, the total catalytic activity is not affected in patients with $\mathrm{CF}$. The overall sensitivity of cAMP-dependent protein kinase to cAMP is also unaffected in CF. These results suggest that if $\mathrm{CF}$ reflects a defect in the cAMP-dependent protein kinase, the isozyme involved represents a small fraction of the total. Alternatively, the deficient $\beta$-adrenergic response in these cells may stem from a defect further down the regulatory chain that leads to the apical $\mathrm{Cl}^{-}$channel. Very little is known about this pathway, which may simply consist of the kinase acting directly on the channel or may involve one or more intermediary steps.

\section{Acknowledgments}

We thank Ella Highland for technical assistance.

This work was supported by National Institutes of Health Program Project Grant HL-24136, and by grants from the Cystic Fibrosis Research Foundation, Cystic Fibrosis Research Inc. and National Medical Enterprises. Dr. Barthelson was supported by a National Institutes of Health Postdoctoral Fellowship.

\section{References}

1. Quinton, P. M., and J. Bijman. 1983. Higher bioelectric potentials due to decreased $\mathrm{Cl}^{-}$absorption in the sweat glands of patients with cystic fibrosis. $N$. Engl. J. Med. 308:1185-1189.

2. Knowles, M. R., M. J. Stutts, A. Spock, N. Fischer, J. T. Gatzy, and R. C. Boucher. 1983. Abnormal ion permeation through cystic fibrosis respiratory epithelium. Science (Wash. DC). 221:1067-1070.

3. Widdicombe, J. H., M. J. Welsh, and W. E. Finkbeiner. 1985. Cystic fibrosis decreases the apical membrane chloride permeability of monolayers cultured from cells of tracheal epithelium. Proc. Natl. Acad. Sci. USA. 82:6167-6171.

4. Sato, K., and F. Sato. 1984. Defective beta adrenergic response of cystic fibrosis sweat glands in vivo and in vitro. J. Clin. Invest. 73:1763-1771.

5. Smith, P. L., M. J. Welsh, J. S. Stoff, and R. A. Frizzell. 1982. Chloride secretion by canine tracheal epithelium. I. Role of intracellular cAMP levels. J. Membr. Biol. 70:215-226.

6. Widdicombe, J. H. 1986. Cystic fibrosis and $\beta$-adrenergic response of airway epithelial cell cultures. Am. J. Physiol. 251:R818R822.

7. Frizzell, R. A., G. Rechkemmer, and R. L. Shoemaker. 1986. Altered regulation of airway epithelial cell chloride channels in cystic fibrosis. Science (Wash. DC). 233:558-560.

8. Welsh, M. J., and C. M. Liedtke. 1986. Chloride and potassium channels in cystic fibrosis airway epithelia. Nature (Lond.). 322:467470.

9. Greengard, P. 1978. Phosphorylated proteins as physiological effectors. Science (Wash. DC). 199:146-152.

10. Huganir, R. L., A. H. Delcour, P. Greengard, and G. P. Hess. 1986. Phosphorylation of the nicotinic acetylcholine receptor regulates its rate of desensitization. Nature (Lond.). 321:774-776.

11. Levitan, I. B. 1985. Phosphorylation of ion channels. J. Membr. Biol. 87:177-190.

12. Widdicombe, J. H., D. L. Coleman, W. E. Finkbeiner, and I. K. Tuet. 1985. Electrical properties of monolayers cultured from cells of human tracheal mucosa. J. Appl. Physiol. 58:1729-1735. 
13. Coleman, D. L., I. K. Tuet, and J. H. Widdicombe. 1984. Electrical properties of dog tracheal epithelial cells grown in monolayer culture. Am. J. Physiol. 246:C355-C359.

14. Burnham, D. B., and J. A. Williams. 1984. Activation of protein kinase activity in pancreatic acini by calcium and cAMP. Am. J. Physiol. 246:G500-G508.

15. Penefsky, H. S. 1977. Reversible binding of $P_{i}$ by beef heart mitochondrial adenosine triphosphatase. J. Biol. Chem. 252:28912899.

16. Laemmli, U. K. 1970. Cleavage of structural proteins during the assembly of the head of bacteriophage T4. Nature (Lond.). 227:680-685.

17. Corbin, J. D., P. H. Sugden, T. M. Lincoln, and S. L. Keely. 1977. Compartmentalization of adenosine 3':5'-monophosphate and adenosine 3 ':5'-monophosphate-dependent protein kinase in heart tissue. J. Biol. Chem. 252:3854-3861.

18. Ekanger, R., T.-E. Sand, D. Ogreid, T. Christoffersen, and S. O. Doskeland. 1985. The separate estimation of cAMP intracellularly bound to the regulatory subunits of protein kinase I and II in glucagon-stimulated rat hepatocytes. J. Biol. Chem. 260:3393-3401.
19. Hofmann, F., J. A. Beavo, P. J. Bechtel, and E. G. Krebs. 1975. Comparison of adenosine $3^{\prime}: 5^{\prime}$-monophosphate-dependent protein kinases from rabbit skeletal and bovine heart muscle. J. Biol. Chem. 250:7795-7801.

20. Beavo, J. A., P. J. Bechtel, and E. G. Krebs. 1974. Activation of protein kinase by physiological concentrations of cyclic AMP. Proc. Natl. Acad. Sci. USA. 71:3580-3583.

21. Beavo, J. A., P. J. Bechtel, and E. G. Krebs. 1974. Preparation of homogenous cyclic AMP-dependent protein kinase(s) and its subunits from rabbit skeletal muscle. In Methods in Enzymology. Vol. 38. J. G. Hardman and B. W. O'Malley, editors. Academic Press, San Francisco. 299-308.

22. Kubler, D., M. Gagelmann, W. Pyerin, and V. Kinzel. 1979. Isolation of the catalytic subunits of cyclic AMP-dependent protein kinases from different mammalian tissues on the basis of charge differences of their subunits. Hoppe-Seyler's Z. Physiol. Chem. 360:1421-1431.

23. Buxton, I. L. O., and L. L. Brunton. 1983. Compartments of cyclic AMP and protein kinase in mammalian cardiomyocytes. J. Biol. Chem. 258:10233-10239. 